\title{
The Effect of Coljcin E2 on the Flagellate Euglena gracilis
}

\author{
By J. ک̌ MARDA \\ Department of Biology, Medical Faculty, Purkyně University, Brno, Czechoslovakia \\ L. EBRIN GER \\ Department of Microbiology, Komenský University, Bratislava, Czechoslovakia \\ AND J. MACH \\ Institute of Sera and Vaccines, Praha, Czechoslovakia \\ (Received 19 November 1973; revised 25 July 1974)
}

\begin{abstract}
Euglena gracilis is very susceptible to a number of exogenous factors. Various antimicrobial chemotherapeutic agents cause distinct changes in it, ranging from temporary inhibition of chlorophyll synthesis to complete and irreversible loss of plastids (Ebringer, 1972a). Chloroplasts have various characteristics, including susceptibility to antibiotics, ribosomes of prokaryotic type and specific DNA, on the basis of which a phylogenetic relationship with prokaryotic organisms has been assumed.

Colicin E2 is an antibiotic which causes specific damage to DNA. Its effect on susceptible bacteria of the Enterobacteriaceae commences by release of DNA from the complex with the cytoplasmic membrane (Beppu \& Arima, I97I) and continues by separation of single strands of the DNA duplex, followed by a cleavage of both strands of its helix and their fragmentation (Ringrose, 1970). As the antibiotics which damage DNA by various mechanisms form a group of substances characteristically causing a hereditary elimination of plastids in the species Eu.gracilis (Ebringer, 1972 b), we decided to test the effects of colicin E2 on this green flagellate. We were further encouraged to undertake this study on finding that the cell wall is not necessary for mediation of the biological effect of colicin E2, as has previously been supposed (Šmarda \& Taubeneck, I968; Takagaki, Kunugita \& Matsuhashi, I973).
\end{abstract}

\section{METHODS}

Strain and cultivation of Euglena gracilis. Euglena gracilis, strain z, was grown in a proteose-peptone-tryptone medium (Mego, 1964) at $2 \mathrm{I}$ to $24{ }^{\circ} \mathrm{C}$. Stock cultures were grown in test tubes containing $10 \mathrm{ml}$ of medium. Organisms ( $10000 / \mathrm{ml}$ ) from a 4-day-old culture were used as an inoculum in each experiment.

Production of colicin E2. Escherichia coli strain CA42 (col E2) ${ }^{+}$, obtained from Professor Fredericq (Liège), was used as a source of colicin E2. It was grown in submerged culture (Mach, Celba, Stránský \& Sedlák, I969) using modified tryptic medium containing $6 \%$ (w/v) yeast dialysate and undergoing continuous addition of glucose $(0.5 \%, \mathrm{w} / \mathrm{v})$ and $\mathrm{pH}$ regulation. After $9 \mathrm{~h}$, a titre of $2.26 \times 10^{9}$ lethal units (l.u.) of free colicin E2/ml was reached, using the indicator strain of E. coli KI2 Row by the titration technique of Smarda (1960).

Concentration and purification of colicin E2. The method used was developed by A. Petera (personal communication). The producing strain was centrifuged from the medium using a Sharples supercentrifuge at $62000 \mathrm{~g}$. The supernatant was precipitated twice with ammonium 
sulphate $(657 \mathrm{~g} / \mathrm{l})$ at $\mathrm{pH} 5.6$. The precipitate was resuspended in water and dialysed for 3 days at $4{ }^{\circ} \mathrm{C}$ against $0.02 \mathrm{M}-\mathrm{K}^{e n} \mathrm{Na}$ phosphate buffer. The active substance was twice absorbed on aluminium hydroxide gel, centrifuged and absorbed on DEAE cellulose. After washing, it was precipitated in $30 \%$ ethanol at $-6^{\circ} \mathrm{C}$; the precipitate was again centrifuged, dissolved in saline and lyophilized. The deposit was dissolved in redistilled water, passed through a Millipore filter and again lyophilized in ampoules under vacuum. The contents of one ampoule, when dissolved in $5 \mathrm{ml}$ redistilled water, contained $3.3 \times 10^{1 \mathrm{t}} 1 . \mathrm{u}$. colicin $\mathrm{E} 2 / \mathrm{ml}$. The activity of purified colicin was estimated in lethal units by a slight modification of the method of Šmarda (I960), using the strain E. coli KI 2 Row as indicator. The purity of the colicin E2 was checked by quantitative determination of total nitrogen $(9 . \mathrm{I} \%, \mathrm{w} / \mathrm{w})$ and phosphorus $(0.03 \% \mathrm{w} / \mathrm{w})$ and by paper electrophoresis: the electrophoretic pattern displayed four distinct fractions, all of which had colicin E2 activity.

Experimental procedure. Immediately before each experiment, the lypohilized colicin E2 was dissolved in the cultivation medium for Euglena and added to the test tubes containing inoculated organisms at the concentrations stated. Experimental details, estimation of chlorophyll and cell counts were as described by Ebringer, Nemec, Sántová \& Foltínová (1970).

Adsorption experiments were done under the same conditions as cultivation experiments. Colicin E2 was added to newly inoculated Euglena cultures at concentrations ranging from $0 . \mathrm{I}$ to $5000 \mathrm{l}$ l.u./single cell. After incubation for between 24 and $\mathrm{I} 68 \mathrm{~h}$, free colicin was assayed (in lethal units) in individual cultures and its titre compared with that in a sterile solution treated in the same way. In these experiments, $E$. coli $\phi$ was used as an indicator of colicin.

Endotoxin. Escherichia coli endotoxin, used for control experiments, contained $0.193 \%$ dry material. The intravenous toxicity for white mice was: $\mathrm{LD}_{50}, 0.5 \mathrm{mg}$ endotoxin in $0.5 \mathrm{ml}$ solution; dose for total lethality, $0.6 \mathrm{mg}$ in $0.5 \mathrm{ml}$ solution.

\section{RESULTS}

Colicin E2 inhibits both the multiplication of Euglena cells and synthesis of chlorophyll during the first phases of cultivation. In the experiments summarized in Table $\mathrm{I}$, the highest concentration tested $\left(\mathrm{I} \cdot \mathrm{I} 2 \times 10^{9} \mathrm{l} \cdot \mathrm{u} . / \mathrm{ml}\right)$ inhibited the synthesis of chlorophyll after 72 and I $68 \mathrm{~h}$ to 18.9 and $59.6 \%$ of control values, respectively. As the free colicin titre fell, the inhibition of chlorophyll synthesis also decreased.

Similar quantitative effects were also found on the numbers of cells. At the highest concentrations used, colicin E2 inhibited the multiplication of cells, especially during the first days of cultivation.

To exclude the possibility that these effects might have resulted from traces of $E$. coli endotoxin, the presence of which in theory could not be excluded from the colicin E2 preparation used, we tested the action of pure endotoxin on Euglena cells. It exhibited distinct toxicity towards Euglena only at the highest concentration tested $(0.1 \%)$, while at $0.01 \%$ it caused only a weak retardation of growth; at $0.001 \%$ it no longer showed any inhibitory effect. However, endotoxin did not inhibit the synthesis of chlorophyll, even in concentrations only slightly lower than lethal ones. Therefore, endotoxin does not interfere with the inhibition of chlorophyll synthesis by colicin E2 and it is highly improbable that it interferes with the inhibition of growth.

The results of adsorption experiments showed unequivocally that in the presence of 
Table I. Effect of colicin E2 on growth and chlorophyll synthesis of Euglena gracilis

$10^{-8} \times$ Initial
colicin E2 conen
$(1 . \mathrm{u} . / \mathrm{ml})$
I I.2
6.0
3.0
1.5
0.75
0.37
Control

$\begin{array}{cc}\mathrm{IO}^{-3} \times \text { No. of organisms } / \mathrm{ml} \\ \text { media } \\ \text { After } 3 \text { days } & \text { After } 7 \text { days } \\ 107 & 405 \\ 132 & 425 \\ 165 & 550 \\ 205 & 582 \\ 277 & 580 \\ 292 & 600 \\ 295 & 690\end{array}$

\begin{tabular}{|c|c|}
\hline \multicolumn{2}{|c|}{$\begin{array}{c}\text { Chlorophyll }\left(\mu \mathrm{g} / \mathrm{ro}^{7}\right. \\
\text { organisms) }\end{array}$} \\
\hline After 3 days & After 7 days \\
\hline $5 \cdot 3$ & $31 \cdot 8$ \\
\hline $10 \cdot 8$ & $42 \cdot 7$ \\
\hline $17 \cdot 2$ & $49 \cdot 5$ \\
\hline 16.9 & $50 \cdot 9$ \\
\hline $20 \cdot 7$ & $48 \cdot 0$ \\
\hline $29 \cdot 2$ & $52 \cdot 0$ \\
\hline $28 \cdot 0$ & $53 \cdot 3$ \\
\hline
\end{tabular}

Eu. gracilis the amount of free colicin E2 in the cultivation medium decreased, a decrease proportional to the increasing number of cells during cultivation. A decrease of r 3 l.u./ Euglena cell was confirmed. All free colicin was removed from the solution when added at concentrations lower than this, whilst at higher concentrations corresponding amounts remained free.

\section{DISCUSSION}

The question of the specific susceptibility of bacterial cells to colicins is not as clear as had been thought until recently. According to the widely accepted hypothesis of Fredericq \& Gratia (1949) concerning the action of colicins on susceptible strains of the Enterobacteriaceae, there is an initial adsorption of colicin on to a specific receptor situated in the bacterial wall. Nomura (1964) extended this concept by the hypothesis of a specific reversible change caused in the receptor by adsorption of colicin, which mediates its specific inhibitory effect.

However, recent work has shown that bacteria can be susceptible to colicins without the involvement of the cell wall. For example, the cells of stable L-forms of protoplast type, whose surface is formed solely by the cytoplasmic membrane, are susceptible to colicins (Šmarda \& Taubeneck, 1968), as are isolated membrane vesicles (Bhattacharyya, Wendt, Whitney \& Silver, 1970) and disrupted spheroplasts (Takagaki et al. 1973). Hence it must be the cytoplasmic membrane which ultimately determines the susceptibility of the bacteria to a colicin; indeed, the cell wall may interfere with the colicin action by blocking the access of colicin molecules to the membrane. In vitro, colicins $\mathrm{E}_{2}$ and $\mathrm{E}_{3}$ exert their inhibitory effects even in cell-free systems. It thus appears that the action of these two colicins does not always depend on specific binding to a receptor in the wall of a susceptible cell, and hence that the susceptibility to these colicins is more widespread than is indicated by models accepted so far. Our results are in agreement with this assumption.

There are two alternative explanations for the decrease of the free colicin E2 titre in these cultures: the colicin may either be inactivated, e.g. by cellular proteases, or absorbed on Euglena cells. The quantitative relations stated above lead us to favour the latter interpretation.

In some preliminary experiments with a non-purified colicin E2 (contained in filtrates of producer cultures) we obtained about $20 \%$ of aplastidic, heterotrophic mutants (no mutants were obtained with filtrate of colicins EI or K). This frequency highly exceeded the frequency of spontaneous mutations of this type, which is about $2 \%$ during the summer season. In the experiments with purified colicin E2 we did not obtain any heterotrophic mutants, a phenomenon which we cannot explain and wish to examine further. 
The inhibition of chlorophyll synthesis is evidently a result of the interaction of colicin E2 with the chloroplasts, providing additional evidence that these organelles are similar to prokaryotic micro-organisms.

\section{REFEREN CES}

Beppu, T. \& ARIMA, K. (I97 I). Properties of the colicin $\mathbf{E}_{2}$-induced degradation of deoxyribonucleic acid in Escherichia coli. Journal of Biochemistry 70, 263-27I.

Bhattacharyya, P., Wendt, L., Whitney, E. \& Silver, S. (1970). Colicin-tolerant mutants of Escherichia coli: resistance of membranes to colicin $\mathrm{E}_{1}$. Science, New York $\mathbf{1 6 8 , 9 9 8 - 1 0 0 0 .}$

Ebringer, L. $(1972 a)$. Are plastids derived from prokaryotic micro-organisms? Action of antibiotics on chloroplasts of Euglena gracilis. Journal of General Microbiology 7r, 35-52.

EBRINGER, L. (1972b). The action of rubiflavin and other cytostatic antibiotics on Euglena gracilis. Neoplasma I9, 579-589.

Ebringer, L., Nemec, P., Sántová, H. \& Foltínová, P. (1970). Changes of the plastid system of Euglena gracilis induced with streptomycin and dihydrostreptomycin. Archiv für Mikrobiologie 73, 268-280.

FredericQ, P. \& Gratia, A. (1949). Résistance croisée à certaines colicines et à certains bactériophages. Comptes rendus des séances de la Société de biologie $\mathbf{1 4 3}, 560-563$.

Mach, J., Celba, V., Stránskx́, V. \& Sedlák, J. (1969). Production of colicine in semicontinuous and continuous cultivation. In Continuous Cultivation of Microorganisms, pp. 46i-468. Praha: Academia.

MEGo, J. L. (1964). The effect of hadacidin on chloroplast development in non-dividing Euglena cells. Biochimica et biophysica acta 79, $22 \mathrm{I}-225$.

Nomura, M. (1964). Mechanism of action of colicins. Proceedings of the National Academy of Sciences of the United States of America 52, I 514-I 521.

RINGRose, P. (1970). Sedimentation analysis of DNA degradation products resulting from the action of colicin E2 on Escherichia coli. Biochimica et biophysica acta 213, 320-334.

Šmarda, J. (1960). Production of bacteriophage and colicin after UV induction of an Escherichia coli strain. Folia biologica (Praha) 6, 225-232.

SMARDA, J. \& TAUBENECK, U. (1968). Situation of colicin receptors in surface layers of bacterial cells. Journal of General Microbiology 52, I6I-I 72.

Takagaki, Y., Kunugita, K. \& Matsuhashi, M. (1973). Evidence for the direct action of colicin K on aerobic ${ }^{32} \mathrm{P}_{\mathbf{i}}$ uptake in Escherichia coli in vivo and in vitro. Journal of Bacteriology $\mathbf{1} 3,42-50$. 